\title{
Note
}

\section{Effect of Sodium Chloride on the Adsorption of Proteins from Pink Shrimp (Pandalus eous) onto Stainless Steel Surfaces}

\author{
Savitree Ratanasumawong ${ }^{1}$, Tomoaki Hagiwara ${ }^{2 *}$ and Takaharu SAKIYAMA ${ }^{2}$ \\ ${ }^{I}$ Department of Food Science and Technology, Kasetsart University, 50 NgamWong Wan Rd., Chatuchuk, Bangkok, 10900, \\ Thailand \\ ${ }^{2}$ Department of Food Science and Technology, Tokyo University of Marine Science and Technology, Konan 4, Minato, Tokyo \\ 108-8477, Japan
}

Received September 25, 2014; Accepted January 11, 2015

Cross-contamination of protein deposits to other food products can cause serious issues in food plants, where several products might be processed using the same equipment. The key to preventing cross-contamination of foods is the thorough cleaning of work surfaces. To establish an optimum cleaning process for such equipment, understanding of the adhesion behavior of proteins on food-contact surfaces is important. This work aims to examine the effect of sodium chloride $(\mathrm{NaCl})$ on the adsorption of shrimp proteins onto stainless steel surfaces. The presence of $\mathrm{NaCl}$ during extraction slightly increased the ratio of adsorbed total protein, while that of the protein tropomyosin, a major shrimp allergen, decreased. The addition of $\mathrm{NaCl}$ to the shrimp protein extract postextraction had no effect on the ratios of adsorbed total protein and tropomyosin. The addition of $\mathrm{NaCl}$ during extraction affected both the protein composition of the extract and the major type of protein adsorbed onto stainless steel surfaces.

Keywords: adsorption, shrimp protein, stainless steel, tropomyosin, cleaning

\section{Introduction}

The adsorption of proteins onto solid surfaces is an important issue in the food manufacturing sector (Nakanishi et al., 2001). During food processing, protein deposits often form on equipment surfaces. These deposits can act as a nutrient for product spoilage microorganisms and pathogens. Furthermore, in cases where the same equipment is used for the production of other foods, crosscontamination might occur. If these deposits contain allergenic substances, cross-contamination to other food products can cause serious health problems for consumers who are hypersensitive to these allergens. To ensure product safety, a clear understanding of protein adsorption is vital in determining the most effective cleaning procedure for processing equipment.

Among seafoods, shrimp is a known allergen for sensitive humans. The allergen in shrimp is tropomyosin, a heat-stable coiled-coil protein with a molecular weight of between 34 and 38 kDa (Daul et al., 1994; Shanti et al., 1993; Jeoung et al., 1997; Leung et al.,1996; Motoyama et al., 2006). It was previously found that in an aqueous extract of shrimp protein, tropomyosin was adsorbed at higher levels onto stainless steel surfaces than other proteins in the extract (Thammathongchat et al., 2009). This indicated that tropomyosin can easily remain on the surfaces of stainless steel equipment after food processing.

Sodium chloride $(\mathrm{NaCl})$ is often used during the boiling and seasoning of shrimp (Niamnuy et al., 2008). In order to identify optimal cleaning methods, it is necessary to understand the effect of $\mathrm{NaCl}$ on the adsorption of shrimp proteins onto food processing surfaces. The presence of $\mathrm{NaCl}$ increases the ionic strength of 
solvents, which affects the electrostatic interactions and solubility of proteins. The presence or absence of $\mathrm{NaCl}$ in a solvent during protein extraction from shrimp could alter the protein composition of the solution, due to the solubility of individual proteins. It is well known that myofibrillar proteins, including tropomyosin, are highly soluble in high ionic strength solvent, while sarcoplasmic proteins are soluble in water or low ionic strength solution (Shahidi, 1994). In a multi-protein system, the type and level of proteins could affect adsorption levels because of competitive adsorption among proteins (Nonckreman et al., 2007).

In addition, the electrostatic charge of a protein is shielded by $\mathrm{NaCl}$, resulting in reduced protein-protein or protein-surface electrostatic interactions (repulsion and attraction). Reduced electrostatic interactions can alter protein adsorption levels. For example, Luey et al. (1991) reported that the adsorption of $\beta$-lactoglobulin $(\beta-\mathrm{Lg})$ onto a hydrophilic silicon surface at $\mathrm{pH} 8.9$ increased in the presence of $\mathrm{NaCl}$. It was concluded that this increase was caused by reduced electrostatic repulsion between $\beta$-Lg and the surface. On the other hand, Tantipolphan et al. (2007) observed that the presence of $\mathrm{NaCl}$ decreased the amount of adsorbed BSA (positive net charge) on a lecithin film because cations were bound by lecithin, resulting in increased repulsion.

Even though the effect of $\mathrm{NaCl}$ on the adsorption of several proteins has been reported, no reports have dealt with the effect of $\mathrm{NaCl}$ on the amount of adsorbed shrimp proteins on solid surfaces. In this study, shrimp protein extracts obtained under different $\mathrm{NaCl}$ concentrations were used to assess the effects of $\mathrm{NaCl}$ on the amount of adsorbed shrimp proteins on stainless steel surfaces. SDS-PAGE analysis was employed to examine the protein composition of samples extracted using different $\mathrm{NaCl}$ concentrations and to identify the major proteins adsorbed onto stainless steel surfaces.

\section{Materials and Methods}

Shrimp sample Pink shrimp (Pandalus eous) (Amaebi in Japanese) was selected as the sample because it is one of the most abundantly caught shrimp in Japan. Fresh pink shrimp were purchased from the market and stored at $-85^{\circ} \mathrm{C}$ until use.

Stainless steel particles Fine stainless steel particles of SUS 316L (PF-5, diameter $3-5 \mu \mathrm{m}$, specific area $0.57 \mathrm{~m}^{2} / \mathrm{g}$ ) were purchased from EPSON ATMIX Corporation (Aomori, Japan). The fine stainless steel particles provided a large substrate surface area for adsorption. The stainless steel particles were washed prior to the adsorption experiment as described previously (Thammathongchat et al., 2009). Briefly, particles were first washed with $0.1 \mathrm{~N} \mathrm{NaOH}$ at $60^{\circ} \mathrm{C}$ for $2 \mathrm{~h}$. They were then thoroughly rinsed with distilled water, then ethanol, and were subsequently oven-dried at $50^{\circ} \mathrm{C}$.

Preparation of shrimp protein extract Three frozen shrimps were thawed using running tap water. Five grams of shrimp meat was mixed with $100 \mathrm{~mL}$ of $20 \mathrm{mM}$ HEPES (pH 7.3) containing $0 \%$, $3 \%$ or $5 \% \mathrm{NaCl}(\mathrm{w} / \mathrm{v})$ using a Stomacher $(230 \mathrm{rpm}, 3 \mathrm{~min}$,
Stomacher 400 circulator, Seward Ltd., UK). The extract was centrifuged at $4000 \mathrm{rpm}$ for $20 \mathrm{~min}$ and the supernatant was filtered through a $0.45-\mu \mathrm{m}$ syringe filter (Sartorius Stedim Biotech $\mathrm{GmbH}$, Göttingen, Germany) to remove any insoluble substances. The initial protein concentration in the filtrate was measured by the BCA method (Pierce, IL, USA). Next, the protein concentration was adjusted to $1.5 \mathrm{mg} / \mathrm{mL}$ by adding the same buffers as used for extraction. The initial tropomyosin concentration in the filtrate after the adjustment was determined by a sandwich ELISA (Crustacean Tropomyosin Residue ELISA, ELISA SYSTEMS Pty Ltd, Queensland, Australia).

In order to evaluate the effect of ionic strength, the ionic strength of shrimp extracts of identical protein composition was altered by adding $\mathrm{NaCl}$ as follows. The extract was obtained by mixing $5 \mathrm{~g}$ of shrimp meat with $100 \mathrm{~mL}$ of $20 \mathrm{mM}$ HEPES (pH 7.3) without $\mathrm{NaCl}$ using a Stomacher; the sample was then centrifuged and filtered as described above. After adjustment of the total protein concentration to $1.5 \mathrm{mg} / \mathrm{mL}$ and measurement of tropomyosin concentration, $\mathrm{NaCl}$ was added at a final concentration of $0,3 \%$ or $5 \% \mathrm{NaCl}(\mathrm{w} / \mathrm{v})$.

Adsorption experiment The adsorption experiment was conducted using the depletion method as previously described (Thammathongchat et al., 2009). A 1-mL aliquot of shrimp protein extract was added to a $20-\mathrm{mL}$ glass bottle containing $2 \mathrm{~g}$ of stainless steel particles. The bottle was then tightly sealed and incubated at $25^{\circ} \mathrm{C}$ for $2 \mathrm{~h}$ with vigorous shaking (120 rpm). After incubation, the total protein content in the supernatant was measured by the BCA method. The amount of protein adsorbed onto the stainless steel surface, $\mathrm{q}\left[\mu \mathrm{g} / \mathrm{m}^{2}\right]$, was calculated using the following equation:

$$
\mathrm{q}=\frac{\left(C_{\mathrm{i}}-C_{\mathrm{e}}\right) \times V}{W \times S_{\mathrm{ss}}}
$$

where $C_{\mathrm{i}}$ is the concentration in the extract before adsorption $[\mu \mathrm{g} / \mathrm{mL}]$, $C_{\mathrm{e}}$ is the concentration in the supernatant after adsorption $[\mu \mathrm{g} / \mathrm{mL}], V$ is the volume of extract in the bottle $[\mathrm{mL}], W$ is the weight of stainless steel particles [g], and $S_{\mathrm{ss}}$ is the specific surface area of stainless steel particles $\left[\mathrm{m}^{2} / \mathrm{g}\right]$, respectively. The procedure mentioned above was conducted in triplicate. The amount of adsorbed tropomyosin was also evaluated using a sandwich ELISA, as conducted for total protein.

Sodium dodecyl sulfate-polyacrylamide gel electrophoresis (SDS-PAGE) In order to examine the composition of shrimp protein extracts and the major types of proteins adsorbed, SDSPAGE was conducted according to the Laemmli method as follows. The protein sample was mixed with a dissolving solution $(1 \%(\mathrm{w} / \mathrm{v})$ SDS, $50 \mathrm{mM}$ Tris-HCl buffer ( $\mathrm{pH}$ 6.8), 20\% (v/v) glycerol, and 1\% $(\mathrm{v} / \mathrm{v})$ mercaptoethanol) at a ratio of $1: 1$ and heated at $100^{\circ} \mathrm{C}$ for 10 min. Each sample $(10 \mu \mathrm{L})$ was loaded onto a $15 \%$ PAGELCompact precast gel (Atto Co., Tokyo, Japan) and subjected to electrophoresis at a constant current of $20 \mathrm{~mA}$ using a CompactPAGE apparatus (Atto Co.). Protein standard mixtures with a molecular weight ranging from 14.2 to $66 \mathrm{kDa}$ (Sigma Chemical 
Co., USA) and from 14.3 to $97.2 \mathrm{kDa}$ (Atto Co.) were used. After separation, the gel was stained with $0.1 \%$ (w/v) Brilliant Blue R (Sigma Chemical Co.) in 30\% (v/v) methanol and 10\% (v/v) acetic acid and destained with $30 \%(\mathrm{v} / \mathrm{v})$ methanol and 10\% (v/v) acetic acid. The stained gel was scanned using a PM-A940 flatbed scanner (Seiko Epson Corp., Suwa, Japan) and the image was digitally recorded.

\section{Results}

Effect of $\mathrm{NaCl}$ addition during protein extraction Figure 1 shows the amounts of adsorbed total protein and tropomyosin in extracts with added $\mathrm{NaCl}$, relative to the initial amounts. The addition of $\mathrm{NaCl}$ slightly increased the amount of total protein adsorbed, while that of tropomyosin clearly decreased. This result indicated that tropomyosin adsorption decreased in the presence of $\mathrm{NaCl}$ during extraction.

Effect of ionic strength on adsorbed tropomyosin levels Figure 2 shows the adsorption of tropomyosin and total protein in extracts with identical protein composition and different $\mathrm{NaCl}$ concentrations. The amounts of adsorbed total protein and tropomyosin did not significantly differ among samples. Thus, the increase in ionic strength (with the addition of $3 \%$ or $5 \% \mathrm{NaCl}$ ) did not have a large impact on the amounts of adsorbed total protein and tropomyosin on stainless steel surfaces under identical protein levels. Tropomyosin adsorption was higher than that for total protein in all extracts. This indicates that tropomyosin was more readily adsorbed than other proteins, results that are supported by our previous report (Thammathongchat et al., 2009) on the amount of adsorbed tropomyosin from an aqueous shrimp extract.

$S D S$-PAGE Figure 3 shows protein banding patterns of samples extracted with various concentrations of $\mathrm{NaCl}$ before and after incubation with stainless steel particles. The number and position of protein bands in samples extracted with $\mathrm{NaCl}$ were similar, regardless of $\mathrm{NaCl}$ concentration. Protein bands with molecular weights of $24 \mathrm{kDa}, 36 \mathrm{kDa}, 40 \mathrm{kDa}$, and $>66 \mathrm{kDa}$ were found in the results of SDS-PAGE analysis. The protein pattern was similar to that of myofibrillar proteins in black tiger shrimp and white shrimp (Sriket et al., 2007), except that myosin heavy chain (MHC, molecular weight of approx. $200 \mathrm{kDa}$ ) was not found in our samples. It was reported that MHC of white shrimp was largely hydrolyzed by endogenous proteinase in the presence of $\mathrm{NaCl}$ (Eakpetch, Benjakul, Visessanguan, \& Kiroongrojana, 2008). This is because $\mathrm{NaCl}$ increases the solubility of muscle protein through the dissociation of myofilaments, resulting in the effective attachment of proteinases to proteins (Eakpetch, Benjakul, Visessanguan, \& Kiroongrojana, 2008). Since $\mathrm{NaCl}$ was present in our samples during extraction, MHC autolysis was likely to have occurred, even though a different type of shrimp was employed.

In contrast, fewer protein bands were observed in samples extracted without $\mathrm{NaCl}$, which confirmed that the protein composition of samples extracted without $\mathrm{NaCl}$ differed from that

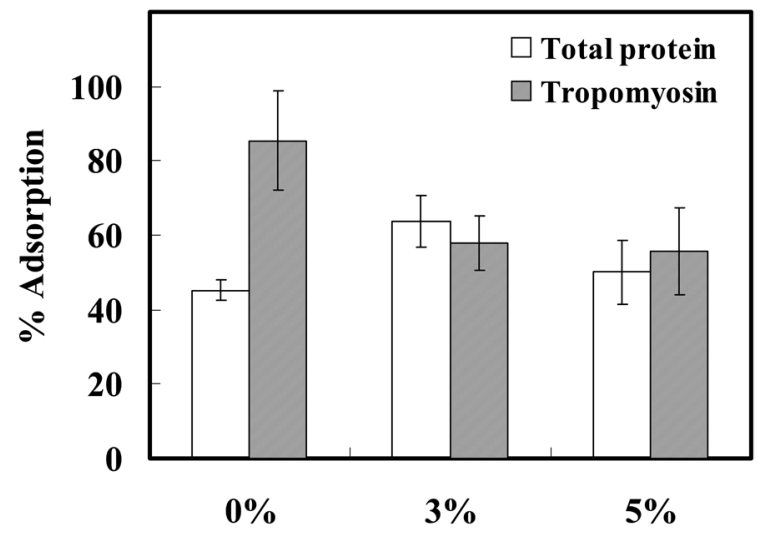

Concentration of $\mathrm{NaCl}(\% \mathrm{w} / \mathrm{v})$

Fig. 1. Effects of $\mathrm{NaCl}$ addition during extraction on the amount of adsorbed total protein and tropomyosin on stainless steel surfaces at $25^{\circ} \mathrm{C}$.

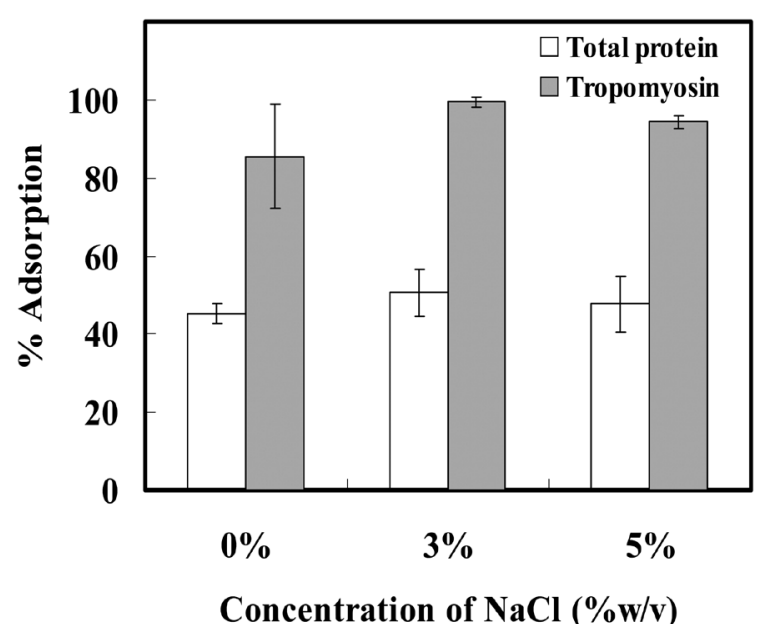

Fig. 2. Effects of $\mathrm{NaCl}$ addition after extraction on the amount of adsorbed total protein and tropomyosin on stainless steel surfaces at $25^{\circ} \mathrm{C}$.

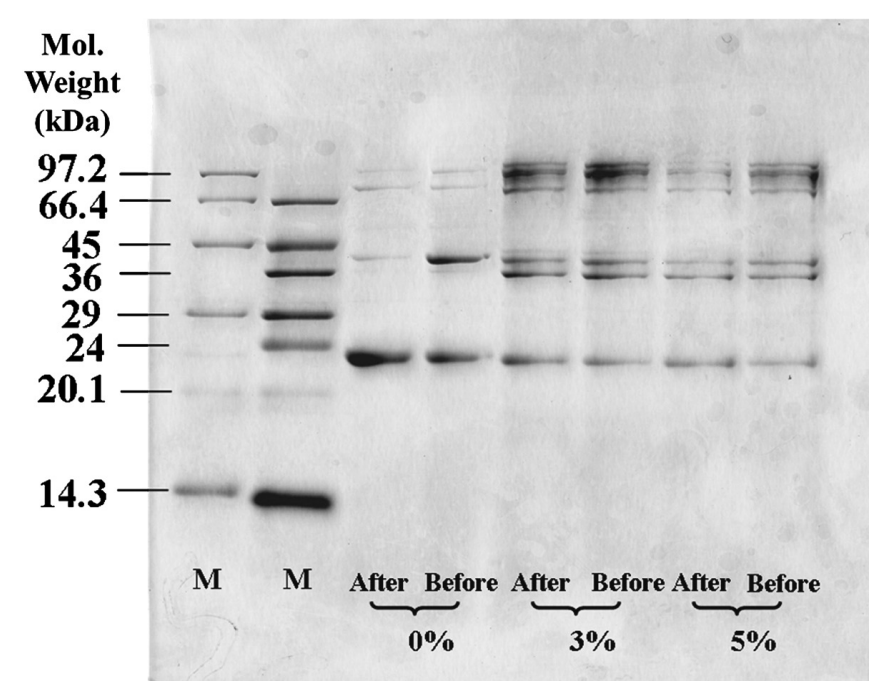

Fig. 3. SDS-PAGE analysis of protein composition in shrimp protein solutions with different $\mathrm{NaCl}$ concentrations before and after the adsorption experiment. $\mathrm{M}$, molecular weight marker. 
with $\mathrm{NaCl}$. The $>66 \mathrm{kDa}$ protein band was weakly observed, while the predominant protein bands were $24 \mathrm{kDa}$ and $40 \mathrm{kDa}$ in size. This protein banding pattern was similar to that observed for sarcoplasmic proteins from black tiger shrimp (Sriket et al., 2007).

After incubation, high molecular weight protein $(>66 \mathrm{kDa})$ bands of samples extracted with $\mathrm{NaCl}$ were clearly decreased. As for the sample extracted in the absence of $\mathrm{NaCl}$, the intensity of the $40 \mathrm{kDa}$ band decreased after incubation and the $36 \mathrm{kDa}$ band disappeared. Both of these proteins may be dominant proteins adsorbed onto stainless steel surfaces.

\section{Discussion}

The ratio of adsorbed tropomyosin to total protein decreased in the presence of $3 \%$ and $5 \% \mathrm{NaCl}$ during extraction (Fig. 1). Because extracts with the same protein composition, containing different $\mathrm{NaCl}$ concentrations, had no effect on the amount of adsorbed tropomyosin on stainless steel surfaces (Fig. 2), the presence of $\mathrm{NaCl}$ during extraction may be the reason for the decreased amount of adsorbed tropomyosin. The presence of $\mathrm{NaCl}$ during extraction resulted in differences in protein composition among extracts (Fig. $3)$. Therefore, differences in protein composition may be the main reason for the decreased affinity of tropomyosin for stainless steel surfaces.

The results of SDS-PAGE analysis revealed that the intensity of protein bands $>66 \mathrm{kDa}$ in size from samples extracted in the presence of $\mathrm{NaCl}$ clearly decreased after incubation. This implied that these proteins may be the dominant proteins adsorbed on stainless steel surfaces with tropomyosin.

In a multi-protein system, competitive adsorption between proteins likely occurs (Green, Davies, Roberts, \& Tendler, 1999). Nonckreman et al. (2007) investigated the adsorption of human fibrinogen (Fg) and human serum albumin (HSA) on glass and polystyrene surfaces. Competitive adsorption was observed between Fg and HSA, and the amount of each protein adsorbed was lower than with single adsorption. Ying et al. (2003) studied the adsorption of a collagen and BSA mixture onto hydrophilic and hydrophobic surfaces. The type of protein adsorbed on the surface was dependent on the binding affinity between the surface and protein. In the current study, proteins $>66 \mathrm{kDa}$ may be adsorbed competitively with tropomyosin in samples extracted in the presence of $\mathrm{NaCl}$, resulting in decreased tropomyosin adsorption.

Even though the amount of adsorbed tropomyosin decreased in the presence of $\mathrm{NaCl}$ during extraction, the amount of adsorbed tropomyosin from samples extracted in the presence of $\mathrm{NaCl}$ $\left(51.8 \pm 14.6 \mu \mathrm{g} / \mathrm{m}^{2}\right.$ in $3 \% \mathrm{NaCl}$ and $45.5 \pm 17.9 \mu \mathrm{g} / \mathrm{m}^{2}$ in $\left.5 \% \mathrm{NaCl}\right)$ was higher than that extracted in the absence of $\mathrm{NaCl}$ $\left(6.91 \pm 4.82 \mu \mathrm{g} / \mathrm{m}^{2}\right)$. This can be attributed to the higher initial tropomyosin level in samples extracted with $\mathrm{NaCl}(90.2 \pm 16.0 \mu \mathrm{g} /$ $\mathrm{mL}$ in $3 \% \mathrm{NaCl}$ and $88.7 \pm 31.0 \mu \mathrm{g} / \mathrm{mL}$ in $5 \% \mathrm{NaCl}$ ) than that extracted in the absence of $\mathrm{NaCl}(10.1 \pm 8.4 \mu \mathrm{g} / \mathrm{mL})$. The reason for the higher tropomyosin content in the $\mathrm{NaCl}$ extracted sample is that tropomyosin is soluble in $\mathrm{NaCl}$ solutions (Shahidi, 1994). Therefore, there is a high possibility that tropomyosin is deposited onto equipment surfaces during food processing with $\mathrm{NaCl}$.

Generally, the presence of $\mathrm{NaCl}$ in a solution increases its ionic strength, affecting electrostatic interactions. As the ionic strength increases, the surface charge of proteins is increasingly shielded. This results in less repulsion or attraction between proteins and surfaces. In this work, the addition of $\mathrm{NaCl}$ in extracts after extraction had no significant effect on the amount of adsorbed tropomyosin. A similar result was reported by Pradier et al. (2007) for polylysine adsorption on an alumina surface. They observed that the presence of $\mathrm{CaCl}_{2}$ did not significantly alter the amount of polylysine adsorbed. In fact, several factors, such as the characteristics of proteins (structure and molecular weight) and surfaces, and other interactions (Van der Waals, hydrophobic, etc.) are also involved in protein adsorption onto solid surfaces (Nakanishi et al., 2001). These factors may have a greater influence than electrostatic interactions on regulating the adsorption of shrimp proteins on stainless steel surfaces.

The amount of total protein adsorbed onto stainless steel surfaces was estimated to be about $0.6-0.9 \mathrm{mg} / \mathrm{m}^{2}$ in this study. The shrimp extract was prepared by mixing $5 \mathrm{~g}$ of shrimp meat and $100 \mathrm{~mL}$ of buffer. This may correspond to the actual manufacturing process of making surimi or minced shrimp. With respect to the stainless steel surfaces of the grinding or mincing machines used in surimi or minced shrimp production, more total protein may be adsorbed because of the decreased amount of water employed, resulting in greater protein content compared to the extract assessed in this study.

Currently, several protein detection methods are commercially available for assessing food manufacturing equipment post-cleaning, the majority of which are based on the swabbing method. The upper detection limit among kits is $1 \sim 3 \mu \mathrm{g}$ protein (3M Food Safety Department (2010); SteriTec Products Inc. (2013)). In order to recover $1 \mu \mathrm{g}$ of protein from a stainless steel surface contaminated with the same protein level as in this study $\left(0.6-0.9 \mathrm{mg} / \mathrm{m}^{2}\right)$, an 11 to $17 \mathrm{~cm}^{2}$ area must be swabbed. As the swabbing of such a surface area is practical, the protein detection kit mentioned above may be capable of verifying the cleaning process for food manufacturing equipment contaminated with the same level of shrimp protein as in this study.

\section{Conclusion}

The effect of $\mathrm{NaCl}$ addition during shrimp extraction on the amount of adsorbed proteins was examined. The addition of $\mathrm{NaCl}$ during extraction slightly increased the amount of total protein adsorbed, while the amount of adsorbed tropomyosin was clearly decreased. The addition of $\mathrm{NaCl}$ after extraction had no effect on the amounts of adsorbed total protein and tropomyosin. Results of SDS-PAGE analysis suggested that proteins $>66 \mathrm{kDa}$ in size were the dominant proteins that showed competitive adsorption with tropomyosin on stainless steel surfaces. 
Acknowledgement This work was supported by a research project fund from JGC-S SCHOLARSHIP FOUNDATION.

\section{References}

3M Food Safety Department (2010). Brochure of 3MTM Clean-Trace ${ }^{\mathrm{TM}}$ Surface Protein (Allergen). St. Paul, MN.

Daul, C.B., Slattery, M., Reese, G., and Lehrer, S.B. (1994). Identification of the major brown shrimp (Penaeus aztecus) allergen as the muscle protein tropomyosin. International Archives of Allergy and Immunology, 105, 49-55.

Eakpetch, P., Benjakul, S., Visessanguan, W., and Kijroongrojana, K. (2008). Autolysis of pacific white shrimp (Litopenaeus vannamei) meat : characterization and the effects of protein additives. Journal of Food Science, 73, 95-103.

Green, R.J., Davies, M.C., Roberts, C.J., and Tendler, S.J.B. (1999). Competitive protein adsorption as observed by surface Plasmon resonance. Biomaterials, 20, 385-391.

Jeoung, B., Reese, G., Hauck, P., Oliver, J.B., Dual, C.B., and Lehrer, S.B. (1997). Quantification of the major brown shrimp allergen Pen a 1 (tropomyosin) by a monoclonal antibody-based sandwich ELISA. Journal of Allergy and Clinical Immunology, 100, 229-234.

Leung, P.S.C., Chow, W.K., Duffey, S., Kwan, H.S., Gershwin, M.E., and Chu, K.H. (1996). IgE reactivity against a cross-reactive allergen in crustacea and mollusca: Evidence for tropomyosin as the common allergen. Journal of Allergy and Clinical Immunology, 98, 954-961.

Luey, J., McGuire, J., and Sproull, R.D. (1991). The effect of $\mathrm{pH}$ and $\mathrm{NaCl}$ concentration on adsorption of $\beta$-lactoglobulin at hydrophilic and hydrophobic silicon surfaces. Journal of Colloid and Interface Science, 43, 489-500

Motoyama, K., Ishizaki, S., Nagashima, Y., and Shiomi, K. (2006). Cephalopod tropomyosins: Identification as major allergens and molecular cloning. Food and Chemical Toxicology, 44, 1997-2002.

Nakanishi, K., Sakiyama, T., and Imamura, K. (2001). On the adsorption of proteins on solid surfaces, a common but very complicated phenomenon.
Journal of Bioscience and Bioengineering, 91, 233-244.

Niamnuy, C., Devahastin, S., and Soponronnarit, S. (2008). Change in protein compositions and their effects on physical changes of shrimp during boiling in salt solution. Food Chemistry, 108, 165-175.

Nonckreman, C.J., Rouxhet, P.G., and Dupont-Gillain, C.C. (2007). Dual radiolabeling to study protein adsorption competition in relation with hemocompatibility. Journal of Biomedical Materials Research Part A, DOI: 10.1002/jbm.a.31111, 791-802.

Pradier, C.M., Humblot, V., Stievano, L., Méthivier, C., and Lambert, J.F. (2007). Salt concentration and $\mathrm{pH}$-dependent adsorption of two polypeptides on plannar and divided alumina surfaces. In situ IR investigations. Langmuir, 23, 2463-2471.

Shahidi, F. (1994). Seafood proteins and preparation of protein concentrates. In Shahidi, F. \& Botta, J.R., Seafoods Chemistry, Processing Technology and Quality (pp. 3-9). London: Chapman \& Hall.

Shanti, K.N., Martin, B.M., Nagpal, S., Metcalfe, D.D., and Subba Rao, P.V. (1993). Identification of tropomyosin as the major shrimp allergen and characterization of its IgE-binding epitopes. The Journal of Immunology, 151, 5354-5363.

Sriket, P., Benjakul, S., Visessanguan, W., and Kijroongrojana, K. (2007). Comparative studies on chemical composition and thermal properties of black tiger shrimp. Food Chemistry, 103, 1199-1207.

SteriTec Products, Inc. (2013). Brochure of Wash-Checks ${ }^{\circledR}$ Pro. Englewood, CO.

Tantipolphan, R., Rades, T., McQuillan, A.J., and Medlicott, N.J. (2007). Adsorption of bovine serum albumin (BSA) onto lecithin studied by attenuated total reflectance Fourier transform infrared (ATR-FTIR) spectroscopy. International Journal of Pharmaceutics, 337, 40-47.

Thammathongchat, S., Hagiwara, T., and Sakiyama, T. (2010). Adsorption of tropomyosin from pink shrimp (Pandalus eous) on stainless steel surface. Food Control, 21, 1250-1253.

Ying, P., Yu, Y., Jin, G., and Tao, Z. (2003). Competitive protein adsorption studied with atomic force microscopy and imaging ellipsometry. Colloids and Surfaces B: Biointerfaces, 32, 1-10. 